\title{
DAO wt Allele
}

National Cancer Institute

\section{Source}

National Cancer Institute. DAO wt Allele. NCI Thesaurus. Code C124941.

Human DAO wild-type allele is located in the vicinity of $12 \mathrm{q} 24$ and is approximately $42 \mathrm{~kb}$ in length. This allele, which encodes D-amino-acid oxidase protein, plays a role in amino acid modification. Mutation of the gene is associated with schizophrenia and may be associated with familial amyotrophic lateral sclerosis. 